\title{
A Construção do Tempo da História e do Tempo da Fiç̧ão em Obras de Eça de Queirós e Fernando Pessoa
}

\author{
Fernando Ferreira da Cunha Neto
}

\begin{abstract}
Resumo
Neste ensaio discutimos a construção ficcional do tempo em obras de Eça de Queirós e Fernando Pessoa, especialmente, em A ilustre casa de Ramires, do primeiro, e em Mensagem, do segundo. Nossa principal assertiva é a da remanufaturação, na tessitura das obras, de um tempo que chamamos intraliterário.
\end{abstract}

Palavras-chave: Tempo extraliterário. Tempo intraliterário. A ilustre casa de Ramires. Mensagem.

Bem antes de Pessoa, seu herdeiro extralúcido e cego diante da realidade grosseira que transfigurará como um diamante, Eça viu como um danado. (LOURENÇO, 1997, p. 713).

O trecho do qual nos apropriamos para a introdução deste ensaio sobre as obras, A ilustre casa de Ramires e Mensagem, de Eça de Queirós e Fernando Pessoa, respectivamente, foi extraído de um artigo intitulado "O Tempo de Eça e Eça e o Tempo", ${ }^{1}$ escrito por Eduardo Lourenço, e integra os Anais do III Encontro Internacional de Queirosianos.

Lourenço, no artigo em referência, começa por tipificar o tempo de Eça, ou seja, o período sociohistórico coetâneo do escritor. É a época das transformações que aceleram o tempo - pelo menos aquelas que os registros oficiais gravam como históricas. É a época em que a Geração de 70 - Eça como um de seus principais expoentes - surgirá no cenário do Portugal de fins dos oitocentos. Tempo das convulsões sociais que ameaçam os, ainda persistentes, vestígios aristocráticos oriundos do Antigo Regime. ${ }^{2}$ É uma era que o Eça diplomata - exilado em diversos consulados de Portugal, em Havana, em Bristol e, por fim, em Paris - conheceu e a sabia ainda não de todo adentrada em Portugal. Tempo de uma Modernidade que não trouxera, afinal, a redenção do homem de suas misérias e, em alguns casos, até mesmo acentuara estas últimas.

Apropriando-nos de algumas das obras de Eça de Queirós, o tempo coetâneo do escritor é o de Jacinto, português exilado em Paris, e que vive o brilho/ócio da enfadonha Civilização. ( $E$ também o tempo em que o mesmo fidalgo português - que vivera apartado de seu país - retorna à Tormes de seus antepassados, sua propriedade localizada no norte de Portugal). O "Tempo de Eça" é também o de 
Gonçalo Mendes Ramires, outro fidalgo, o "da Torre", para que bem nos apropriemos do termo que serve como um distintivo, talvez signo/símbolo notabilizador da personagem principal de $A$ ilustre casa de Ramires: período da decadência da nação e da estirpe, os Ramires, que metaforizam Portugal na última obra de Eça.

A existência de um tempo que corre intra e extraliterariamente à(s) obra(s), hipótese que pode ser derivada a partir das colocações de Eduardo Lourenço, é a possibilidade de análise que mais de perto nos interessa. Tentar definir os tempos extraliterário e intraliterário, constituintes das obras dos dois escritores, Eça e Pessoa, é tarefa bastante difícil. Nossa hipótese, derivada de algumas considerações de Lourenço, é a de que, por obra de reapropriações e recriações de elementos típicos da cultura portuguesa, os dois autores lograriam configurar tempos internos e próprios às fabulações culturais por eles criadas, A ilustre casa de Ramires e Mensagem. O tempo extraliterário se nos afigura como algo que pode ser localizado externamente à obra, as confluências sociohistóricas que correriam paralelamente ao ato de produção cultural. Entretanto, o tempo extraliterário constituiria uma espécie de ponte entre o tempo interno à obra, produto da elaboração anteriormente hipotetizada, e os referentes externos consentâneos ao ato de produção cultural: a sociedade, a História, as ciências, etc.. Uma das características deste outro tempo, que tentamos demarcar como intraliterário, é a sua imprecisão ou "indatabilidade". A imprecisão do mesmo se dá em virtude de dois fatores: primeiro, porque ele só se torna tangível pela via textual, elaboração só materializável através da linguagem. A segunda razão da fugacidade do tempo intraliterário está ligada ao fato de que a remanufaturação textual de uma época conecta-se a elementos que constituem um imaginário cultural e, para este último, dificilmente conseguimos estabelecer datas/eras como aquelas demarcadas pelos calendários ao registrarem a passagem do outro tempo, o extraliterário.

Tanto em A ilustre casa de Ramires de Eça de Queirós, quanto em Mensagem de Pessoa, podemos verificar - o mesmo ocorre em $A$ cidade e as serras e na Ode marítima - a coexistência de dois tempos. O primeiro deles é o consentâneo com as vivências/experiências dos dois escritores, os quais podem ser localizados num tempo que os relógios, as datas dos calendários podem aprisionar. É o tempo onde vivem muitas das personagens queirosianas, citadas anteriormente, é o locus onde podemos situar a voz de enunciação da Ode marítima, e é, ainda, o fugidio, eclipsado tempo do qual tenta escapar o eu poético que enuncia, prefigura e prenuncia os novos tempos da Mensagem pessoana.

Para que melhor esclareçamos nosso raciocínio, teremos que destacar alguns aspectos das duas últimas obras de Eça, $A$ cidade e as serras e $A$ ilustre casa de Ramires, e de Ode marítima e Mensagem de Pessoa.

Como já sintetizado em parágrafo anterior, A Cidade e as Serras apresenta-nos o fidalgo português, Jacinto, exilado em Paris, em seu retorno a Portugal - à sua quinta no meio-norte português: montanhoso, agreste, arcaico. O retornado é alguém que já vivenciara e experimentara tudo o que o tempo da civilização, a parisiense, propiciara/acarretara ao homem moderno. Na sua Tormes, Jacinto vivenciará um outro tempo que é duplo. Duplo porque consubstancia um resultado - o Portugal agrário, atrasado, quando contraposto à(s) outra(s) Europa(s), que perdera o "trem da História", e é, também, uma pátria que configura uma outra temporalidade não consentânea com a civilização à época do mesmo personagem, o Jacinto. Tempo de reminiscências fidalgas, que emerge sub-repticiamente com as referências ao passado da fidalguia de cepa que tivera Jacinto como um de seus desaguadouros. Tempo de 
difícil reconstrução porque muitos de seus vestígios ${ }^{3}-$ as ossadas dos antepassados de Jacinto são um exemplo - foram arrancadas de seus sepulcros por intempéries e não puderam ser totalmente reorganizadas para um novo sepultamento.

O segundo tempo, ao qual nos referimos no final do parágrafo anterior, que em $A$ Cidade e as Serras parece apenas se insinuar, em $A$ ilustre casa de Ramires emerge por diversas operações realizadas nas duas narrativas: na encaixada, $A$ Torre de Dom Ramires, novela histórica escrita por Gonçalo Mendes Ramires, e na encaixante, a estrutura maior que lhe é sobreposta. A primeira, a novela histórica escrita pelo Fidalgo da Torre, é aquela das lembranças sobre os ancestrais do mesmo Gonçalo, mas é mais do que estas últimas: é um outro tempo, feito de fragmentos cujas linhagens trespassam a História, tempo este não passível de ser sociohistoricamente capturado pelos calendários, pelos livros de História.

Extraiamos de $A$ ilustre casa de Ramires uma passagem que bem ilustra o trabalho realizado na obra com o tempo. Trata-se de um trecho em que é narrada uma visita do protagonista da obra, Gonçalo Mendes Ramires, personagem-narrador da novela histórica "A Torre de Dom Ramires", ao cemitério de Santa Maria de Craquede.

E pela brecha dum muro a que ainda se amparava um pedaço e altar - penetrou [Gonçalo] na silenciosa crasta afonsina. Só dela restam duas arcadas em ângulo [...] E contra o muro, [...] avultam os sete imensos túmulos dos antiqüíssimos Ramires, denegridos, lisos, sem um lavor, como toscas arcas de granito, alguns pesadamente encravados no lajedo, outros pousando sobre bolas que os séculos lascaram. [...] $\mathrm{Na}$ abóbada, sobre o mais vasto túmulo, lá negrejava chumbada a espada, a famosa espada, com a sua corrente de ferro pendendo do punho, a folha roída pela ferrugem das longas idades. [...] Que Ramires jazeriam nesses cofres de granito, a que o tempo raspara as inscrições e datas, para que nelas toda a História se sumisse, e mais escuramente se volvessem em leve pó sem nome aqueles homens de orgulho e força? [...]. (QUEIRÓS, 1999, p. 324-325). (Grifos nossos).

O tempo que é entretecido na última obra de Eça, o qual chamamos de intraliterário, advém de uma remanufaturação de traços culturais persistentes, perduráveis através dos séculos, os quais Lourenço evidencia em seu trabalho. Tomemos o trecho no qual ele cita os elementos que nós apreendemos como a matéria utilizada por Eça na remanufaturação cultural do tempo.

Eça de Queirós foi, como talvez só Camões o tenha sido para o seu tempo, um grande consumidor de alimentos terrestres, de fantasmas da imaginação alheia, de mitos culturais, de ícones históricos, de legendas, de tudo que em qualquer ordem, a Beleza desejo redimido pela forma - forneceu à sua fome de ficção e mitificação inatas. Tudo Ihe foi tema e motivo para glosa e re-criação. A literatura como imaginário constituído foi sem dúvida, e assim para todos os escritores, a fonte das fontes. (LOURENÇO, 1997, p. 711). (Grifos nossos).

Retomemos, agora, Pessoa, também sucintamente, buscando vestígios em composições do poeta deste outro tempo, produto da remanufaturação de traços da cultura portuguesa.

Na Ode marítima, é nítido o momento a partir do qual o sujeito poético zarpa para a infinita distância, fazendo ressurgir, através da reapropriação literária de traços do universo cultural português, uma outra dimensão de realidade. $O$ sujeito poético, em dois de seus versos, confessa o esforço que realiza para trazer de volta o que vai recriando pelo artifício da linguagem - do literário: /Esforço-me e consigo chamar outra vez ante os meus olhos na alma, /Outra vez, mas através de uma imaginação quase literária/ A fúria da pirataria, da chacina, o apetite, quase do paladar, do saque,/ (PESSOA, 1986b, p. 265). (Grifo do autor). 
Este tempo, o qual o sujeito lírico de Ode marítima realiza esforços para trazer de volta, delata o que chamamos anteriormente de dois tempos. Uma temporalidade paralela à época da elaboração do poema, que é também matéria da obra, constituindo uma espécie de seu vértice externo, às vezes referenciado, às vezes negado, e um outro que, como assinalado por Lourenço, é o produto de um consumo: "de fantasmas da imaginação alheia, de ícones históricos, de legendas..." (LOURENÇO, 1997, p. 711).

Tomando a Mensagem do ortônimo Pessoa, diríamos: se o tempo da enunciação, enquanto um presente, sociohistoricamente datável, esfuma-se, isso ocorre em virtude de todas as operações e esforços realizados pelo eu poético para a prefiguração de um outro tempo - também a manufatura textual dos mesmos alimentos terrestres especificados por Lourenço. O local de enunciação na Mensagem, através do qual podemos entrever o tempo - presente - vivido pelo poeta, é eclipsado por obra das manobras do sujeito lírico, e em função do que Lourenço aponta como a cegueira do criador dos heterônimos em face da realidade que o cercava. Realidade que o herdeiro "extralúcido" de Eça transfigura em um outro tempo, porque, como Eça, ele via "como um danado".

Vejamos um poema que bem elucida a diretiva anterior. Trata-se de "Nevoeiro", a última composição de "O Encoberto", terceira e última parte da nau-nação pessoana, Mensagem.

Nem rei nem lei, nem paz nem guerra,

Define com perfil e ser

Este fulgor baço da terra

Que é Portugal a entristecer -

Brilho sem luz e sem arder,

Como o que o fogo-fátuo encerra.

Ninguém sabe que coisa quer.

Ninguém conhece que alma tem,

Nem o que é mal nem o que é bem.

(Que Ânsia distante perto chora?)

Tudo é incerto e derradeiro.

Tudo é disperso, nada é inteiro.

Ó Portugal, hoje és nevoeiro.

(PESSOA, 1998, p. 95) (Grifos nossos).

O tempo que o sujeito lírico de Mensagem eclipsa, principalmente na última parte do livro, "O Encoberto", é a antípoda de uma "outra época", surgida por obra da tessitura de um tempo, de que os versos de "Padrão", poema que integra a segunda parte da nau-nação de Pessoa, "Mar Português", nos encena:

$[\ldots]$

E ao imenso e possível oceano

Ensinam estas Quinas, que aqui vês,

Que o mar com fim será grego ou romano:

O mar sem fim é português.

E a Cruz no alto diz que o que me há na alma

E faz a febre em mim de navegar

Só encontrará de deus na eterna calma

O porto sempre por achar.

(PESSOA, 1998, p. 55)

Por último, acrescentaríamos que a configuração destes outros tempos - um tempo de Eça e um tempo de Pessoa - produtos da manufatura textual que nos 
alcança através das produções dos dois escritores, invertendo o sentido dado por Lourenço à expressão, "O Tempo de Eça" em seu ensaio e, ainda, acrescendo um tempo de Pessoa com a significância por nós vislumbrada, só pode se dar pela via da recriação de elementos do imaginário cultural português, já de muito longe trabalhados pelos dois escritores. Os dois tempos, que integram a tessitura de Mensagem de Pessoa e de $A$ ilustre casa de Ramires de Eça, são um tempo remanufaturado, porque se distanciam daquele que Ihes corre em paralelo, referência a um extraliterário, ao linear, oco da história teleológica que, no caso específico do Portugal de fins do século XIX e começos do XX, apontava para um destino desalentador. Estes tempos, queirosiano e pessoano, aproximam-se daquilo que configuraria um tempo próprio a uma História humanizada. História sustentada e colocada em marchas e contramarchas por traços, cujas linhas os conectam, em algum grau, à multivariegada cultura portuguesa.

Estes outros tempos pessoano e queirosiano, "humanos", conformam uma outra História, nas palavras de Lourenço, "vasto repositório de maneiras de ser da humanidade" (LOURENÇO, 1987, p. 712) e ajudam a compor as produções que se consubstanciam em Mensagem e em A Ilustre casa de Ramires.

Notas

LOURENÇO, Eduardo. O Tempo de Eça e Eça e o Tempo. In: MINÉ, Elza; CANIATO, Benilde Justo (Org.). 150 Anos com Eça de Queirós: Anais do III Encontro Internacional de Queirosianos. São Paulo: Centro de Estudos Portugueses/FFLCH/USP, 1997. p. 707-714.

2 O século XIX, principalmente a sua segunda metade, é uma época em que grandes convulsões sociais abalam a Europa. Na verdade, o processo se inicia em fins do século XVIII com a Revolução Francesa. Coincidentemente, será no final do século seguinte que as contradições dos regimes monárquicoparlamentares se acirrarão. O modelo liberal burguês, que era um legado, tanto das transformações econômicas ocorridas na Inglaterra dos séculos XVIII e XIX, quanto das transformações políticas derivadas da Revolução Francesa, ao final do século XIX, mostrava sua face abominável: a exclusão de quase a totalidade da população dos benefícios proporcionados pela industrialização; a existência do voto censitário, o que impedia que a maioria da população participasse dos pleitos eleitorais; enfim, muitas lutas ainda teriam que abalar os países europeus que haviam adotado o modelo político liberal-burguês até que se alargassem os direitos do operariado. É essa outra Europa, de além-Pireneus, convulsionada, que Portugal parece assistir como se nada do que acontecia lá fora lhe dissesse respeito ou o afetasse.

${ }^{3}$ É interessante observarmos, em obras de Eça de Queirós, inúmeras passagens, realizadas através da fala de personagens, e por outras formas engendradas nas narrativas queirosianas, sobre registros históricos que foram apagados por aquilo que talvez pudéssemos chamar de "a mão do tempo". Em $A$ ilustre casa de Ramires, um dos maiores testemunhos desta ação do tempo são as ruínas de Santa Maria de Craquede, um cemitério, onde se encontravam os sepulcros de remotos ancestrais do "Fidalgo da Torre", o personagem Gonçalo Mendes Ramires. Em Craquede, nas lápides dos túmulos dos valorosos Ramires do passado, já não mais existiam datas, nem nomes. Em $A$ cidade e as serras, uma intempérie da natureza, um terrível temporal fora o responsável pela impossibilidade de resgatar e reunir corretamente as ossadas de ancestrais do fidalgo Jacinto: a forte chuva destruíra os sepulcros de seus antepassados e misturara as ossadas, não permitindo a identificação dos ossos das pessoas que lá haviam sido sepultadas. Cf. QUEIRÓS, Eça de. $A$ cidade e as serras. Belo Horizonte: Editora Itatiaia, 1962. p. 127-128.

Abstract

In this essay we discuss the fictional construction of time in books by Eça de Queirós and Fernando Pessoa, especially in, $A$ Ilustre Casa de Ramires, of the first, and in Mensagem, of the second. Our main goal is the idea of a remake, in the construction of the books, of a time which we call intra literary time. 
Key words: Extra literary time. Intra literary time. A ilustre casa de Ramires. Mensagem.

Referências

FOUCAULT, Michel. A Arqueologia do Saber. 7.ed. Rio de Janeiro: Forense Universitária, 2004.

FOUCAULT, Michel. Microfísica do Poder. 19.ed. São Paulo: Graal, 2004.

FRANÇA, José Augusto. (In)Definições de Cultura. Lisboa: Editorial Presença, 1997.

LOURENÇO, Eduardo. O Labirinto da Saudade. 2.ed. Lisboa: Dom Quixote, 1982.

LOURENÇO, Eduardo. Nós e a Europa ou as duas razões. Lisboa: Imprensa Nacional-Casa da Moeda, 1994.

MINÉ, EIza; CANIATO, Benilde Justo (Org.). 150 Anos com Eça de Queirós: Anais do III Encontro Internacional de Queirosianos. São Paulo: Centro de Estudos Portugueses-FFLCH-USP, 1997. p. 707714.

PERRONE-MOISÉS, Leyla. O futurismo saudosista de Fernando Pessoa. In: Actas do IV Congresso Internacional de Estudos Pessoanos. Maia: Fund. Eng. António de Almeida, 1991. v. 2.

PESSOA, Fernando. Mensagem. São Paulo: Cia. das Letras, 1998.

PESSOA, Fernando. Obra em prosa. Rio de Janeiro: Nova Aguilar, 1986a.

PESSOA, Fernando. Obra poética. Rio de Janeiro: Nova Aguilar, 1986b.

QUEIRÓS, Eça de. A cidade e as serras. Belo Horizonte: Itatiaia, 1962.

QUEIRÓS, Eça de. A correspondência de Fradique Mendes.

Lisboa: Livros do Brasil, [s.d.].

QUEIRÓS, Eça de. A ilustre casa de Ramires. Lisboa: Imprensa Nacional-Casa da Moeda, 1999. Edição Crítica de Elena Losada Soler. 